\title{
SCHUR CONVEXITY AND HADAMARD'S INEQUALITY
}

\author{
Yuming Chu, Gendi Wang And XiAOHui Zhang
}

Abstract. Suppose that $I$ is an open interval and $f: I \rightarrow \mathbb{R}$ is a continuous function. If

$$
F(x, y)= \begin{cases}\frac{1}{y-x} \int_{x}^{y} f(t) d t-f\left(\frac{x+y}{2}\right), & x, y \in I, x \neq y, \\ 0, & x=y \in I,\end{cases}
$$

and

$$
G(x, y)=\left\{\begin{array}{lc}
\frac{f(x)+f(y)}{2}-\frac{1}{y-x} \int_{x}^{y} f(t) d t, & x, y \in I, x \neq y, \\
0, & x=y \in I,
\end{array}\right.
$$

then $F(x, y)$ and $G(x, y)$ are Schur convex (concave) on $I^{2}$ if and only if $f$ is convex (concave) on $I$.

Mathematics subject classification (2010): 26D15, 26A51, 26B25.

Keywords and phrases: Hadamard's inequality, convex function, Schur convex function.

\section{REFERENCES}

[1] S. S. DRAGOMiR, On Hadamard's inequality for the convex mappings defined on a ball in the space and applications, Math. Inequal. Appl., 3 (2000), 177-187.

[2] S. S. DRAGOMIR, A refinement of Hadamard's inequality for isotonic linear functionals, Tamkang J. Math., 24 (1993), 101-106.

[3] S. S. Dragomir, Two mappings in connection to Hadamard's inequalities, J. Math. Anal. Appl., 167 (1992), 49-56.

[4] S. S. Dragomir, Y. J. Cho And S. S. Kim, Inequalities of Hadamard's type for Lipschitzian mappings and their applications, J. Math. Anal. Appl., 245 (2000), 489-501.

[5] S. S. Dragomir and C. E. M. Pearce, Quasilinearity \& Hadamard's inequality, Math. Inequal. Appl., 5 (2002), 463-471.

[6] S. S. Dragomir And C. E. M. Pearce, Quasi-convex functions and Hadamard's inequality, Bull. Austral. Math. Soc., 57 (1998), 377-385.

[7] S. S. Dragomir, J. PeČArić And L. E. Persson, Some inequalities of Hadamard type, Soochow J. Math., 21 (1995), 335-341.

[8] N. Elezović And J. PeČArić, A note on Schur-convex functions, Rocky Mountain J. Math., 30 (2000), 853-856.

[9] P. M. Gill, C. E. M. Pearce And J. PeČArić, Hadamard's inequality for $r$-convex functions, J. Math. Anal. Appl., 215 (1997), 461-470.

[10] A. W. Marshall And I. Olkin, Inequalities: Theory of Majorization and It's Applications, Academic Press, New York, 1979.

[11] M. Matić And J. PeČARIĆ, Notes on inequalities of Hadamard's type for Lipschitzian mappings, Tamkang J. Math., 32 (2001), 127-130.

[12] C. P. Niculescu And L. E. Persson, Convex Function and Their Applications, Springer, New York, 2006.

[13] C. E. M. PeArce, J. PeČArić And V. ŠImić, Stolarsky means and Hadamard's inequality, J. Math. Anal. Appl., 220 (1998), 99-109.

[14] C. E. M. Pearce AND A. M. Rubinov, P-functions, quasi-convex functions, and Hadamard-type inequalities, J. Math. Anal. Appl., 240 (1999), 92-104. 
[15] J. PeČARIĆ AND S. S. DRAGOMIR, A generalization of Hadamard's inequality for isotonic linear functionals, Rad. Math., 7 (1991), 103-107.

[16] A. W. Roberts And D. E. VARberg, Convex Function, Academic Press, New York, 1973.

[17] G.-S. Yang AND M. C. Hong, A note on Hadamard's inequality, Tamkang J. Math., 28 (1997), 33-37.

[18] G.-S. YANG AND H. -L. WU, A refinement of Hadamard's inequality for isotonic linear functionals, Tamkang J. Math., 27 (1996), 327-336. 